\title{
Presence of the Hemolysin Gene of Vibrio mimicus in Fish and Seafood Products in Sonora, México
}

\author{
Iliana Guardiola-Avila ${ }^{1}$, Lorena Noriega-Orozco ${ }^{2}$, Evelia Acedo-Félix ${ }^{1}$, \\ Angela E. Lara ${ }^{3} \&$ Ma Micaela Tapia-Olea ${ }^{3}$ \\ ${ }^{1}$ CIAD-Hermosillo, Hermosillo, Sonora, México \\ ${ }^{2}$ CIAD-Guaymas, Guaymas, Sonora, México \\ ${ }^{3}$ Sonora State Public Health Laboratory, Hermosillo, Sonora, México \\ Correspondence: Lorena Noriega-Orozco, CIAD-Guaymas, Guaymas, Sonora, México, Carr. al Varadero \\ Nacional Km. 6.6, A.P. 248, México. Tel: 52-622-225-2828 ext. 2830. E-mail: lnoriega@ciad.mx
}

Received: September 15, 2014 Accepted: October 28, 2014 Online Published: November 11, 2014

doi:10.5539/jfr.v4n1p66

URL: http://dx.doi.org/10.5539/jfr.v4n1p66

\begin{abstract}
Vibrio mimicus causes diseases in humans in many countries, and it is highly abundant in aquatic environments. The present study evaluated the presence of $V$. mimicus in commonly consumed fish and seafood products in Sonora, México. A total of 262 samples of fish and seafood products were analyzed using PCR to identify the presence of the hemolysin $(\mathrm{vmh})$ gene of $V$. mimicus, which was detected in 32 food samples. The positive food samples included raw (14\%) and ready to eat fish and seafood (9\%). The leading raw products in which $V$. mimicus was detected were crustaceans (57\%), but mollusks represented $78 \%$ of the positive ready-to-eat products (RTE). Therefore, the presence of the $V$. mimicus hemolysin gene in raw and RTE seafood may represent a potential health risk to consumers in northwest México.
\end{abstract}

Keywords: hemolysin vmh, seafood safety, Vibrio mimicus

\section{Introduction}

The Vibrionaceae family is comprised of a variety of important microorganisms (J. Farmer III, 2006), including at least 12 species of clinical concern that are causative agents of human diseases. The primary pathogenic species to humans are Vibrio cholerae, Vibrio parahaemolyticus and Vibrio vulnificus (Daniels \& Shafaie, 2000). However, Vibrio mimicus has been linked to food-borne illnesses in recent years (Adeleye, Daniels, \& Enyinnia, 2010; Chitov, Kirikaew, Yungyune, Ruengprapan, \& Sontikun, 2009; Hlady \& Klontz, 1996; Newton, Kendall, Vugia, Henao, \& Mahon, 2012; Zamudio, 2005).

$V$. mimicus is a Gram-negative, oxidase- and catalase-positive, Voges-Proskauer-negative, mobile bacterium with a polar flagellum. It produces toxins, hemolysins, hemagglutinins, proteases and siderophores (Davis et al., 1981; J. J. Farmer III, Janda, Brenner, Cameron, \& Birkhead, 2005; Hasan et al., 2010). V. mimicus grows at refrigeration temperatures $\left(4^{\circ} \mathrm{C}\right)$, survives under freezing conditions $\left(-30^{\circ} \mathrm{C}\right)$ and tolerates up to $6 \% \mathrm{NaCl}$ (Chowdhury, Yamanaka, Miyoshi, Aziz, \& Shinoda, 1989; Wong, Chen, \& Yu, 1994).

This bacterium is associated with human disease in various countries, such as Bangladesh, Japan, Costa Rica, Mexico, Thailand, the United States, Nigeria, Brazil, Australia and Venezuela. In addition, V. mimicus was isolated from water, plants, sediment and food samples, such as shrimp, crabs, oysters and clams (Adeleye et al., 2010; Begum \& Khan, 2001; Chitov et al., 2009; Davis et al., 1981; Muñoz, Marín, Marval, \& Martínez, 2012; Saad, Edris, Ibrahim-Hemmat, \& Rasha, 2013; Tercero Alburo, 2008; Vieira, Teixeira, Vicente, Momen, \& Salles, 2001; Zamudio, 2005).

Various genetic and molecular methodologies are frequently used to identify bacteria, including bacteria of epidemiological interest. Many molecular methodologies are based on repetitive amplification (ERIC-PCR, GTG5-PCR), random amplified polymorphic DNA (RAPD), restriction-fragment length polymorphism (RFLP, AFLP) and several types of PCR amplification (multiplex PCR or real-time PCR). These methodologies are widely accepted because of their reproducibility, simplicity and discriminatory power (Foley \& Grant, 2007; Ochman, 2001; Prakash et al., 2007; Ramamurthy \& Nair, 2007; Thompson, Iida, \& Swings, 2004). 
V. mimicus produces several extracellular toxic factors, but the most common factor is a heat-labile hemolytic/cytolytic toxin known as V. mimicus hemolysin or VHM (Mizuno et al., 2009; Mizuno, Nanko, Maehara, Shinoda, \& Miyoshi, 2014). The VHM gene, $v m h$, is common to clinical and environmental $V$. mimicus strains, and it is a species-specific identifier (Shinoda et al., 2004; Sultan et al., 2007). Currently, $V$. mimicus is recognized as a human pathogen in the United States by the FDA (Food and Drug Administration), and it is described briefly in their Bacteriology Analytical Manual (Kaysner \& DePaola, 2004). In Mexico, only $V$. cholerae is under a surveillance program by health authorities, but they recognize an average of suspected cholera cases between 3000 and 4000 with a minimal positive cases, probably caused by other Vibrio species (León Robles et al., 2013). Hence, V. mimicus is not reportable in Mexico by the National System of Epidemiological Surveillance (SINAVE), and there are no official statistical information about its incidence. Consequently, V. mimicus may go unnoticed as the causal agent of some of the food-borne diseases in Mexico (Campos et al., 1996; Gonzalez Vazquez, Tercero Alburo, Quiñones-Ramírez, \& Vazquez Salinas, 2005; Tercero Alburo, 2008).

Therefore, the present study focused on the detection of the VMH gene $(\mathrm{vmh})$ in fish and seafood products from Sonora, Mexico, to provide information on the abundance of this bacterium in seafood products and help elucidate whether this bacterium is a microbiological risk for consumers.

\section{Materials and Methods}

\subsection{Sample Processing}

The collection and initial processing of samples were conducted by personnel of the Sonora State Public Health Laboratory (LESP), which is part of the Mexican Ministry of Health. Sampling was conducted according official procedures that were adopted as part of the State Vibrio-surveillance program. Samples were collected from April to October 2011 and transported to the LESP for analysis. A total of 262 food samples (shrimp, scallops, oysters, fish, octopus, and clams, among others) were analyzed. Samples were collected in major cities from 14 different counties of Sonora, Mexico that were divided for statistical purposes in coastal and non-coastal counties (Figure 1). Samples were homogenized in alkaline peptone water (APW) and incubated at $37^{\circ} \mathrm{C}$ for $6 \mathrm{~h}$. For the molecular detection of the $v m h$ gene of $V$. mimicus, $50 \mathrm{~mL}$ of the incubated APW were taken to the Microbiology Laboratory of the Research Center for Food and Development (CIAD) for DNA extraction.

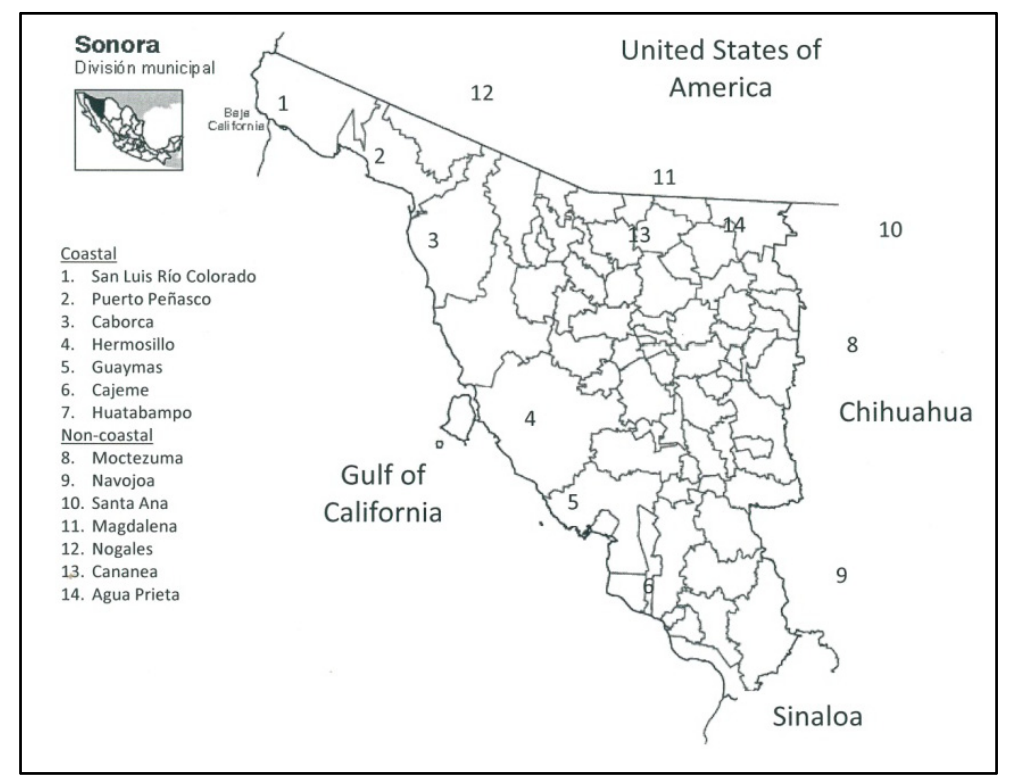

Figure 1. Localization of the seven coastal and seven non-coastal sampled counties in Sonora, Mexico (Instituto Nacional de Estadistica y Geografía [INEGI], 2010) 


\subsection{DNA Extraction}

DNA extraction was based on the method described by Noriega-Orozco, Acedo-Félix, Higuera-Ciapara, Jiménez-Flores, and Cano (2007), with modifications. A 1.5-mL aliquot of APW was suspended in a trypticase soy broth (TSB) containing $1 \% \mathrm{NaCl}$, and the solution was centrifuged $(17,100 \mathrm{~g}$ for $5 \mathrm{~min})$. Then, $500 \mu \mathrm{L}$ of buffer ( $500 \mathrm{mM}$ Tris-HCl, $100 \mathrm{mM} \mathrm{NaCl}, 1 \mathrm{mM}$ sodium citrate), $50 \mu \mathrm{L}$ of lysozyme $(20 \mathrm{mg} / \mathrm{mL})$ and $5 \mu \mathrm{L}$ of mutanolysin $(5 \mathrm{U})$ were added, and the samples were incubated at $37^{\circ} \mathrm{C}$ for $2 \mathrm{~h}$. A total of $50 \mu \mathrm{L}$ of proteinase $\mathrm{K}$ $(20 \mathrm{mg} / \mathrm{mL})$ was added, and the solution was incubated at $50{ }^{\circ} \mathrm{C}$ for $2 \mathrm{~h}$. Subsequently, $500 \mu \mathrm{L}$ of lysis solution (200 mM Tris- $\mathrm{HCl}, 100 \mathrm{mM} \mathrm{NaCl}, 4 \%$ sodium dodecyl sulfate, $1.5 \%$ polyvinylpolypyrrolidone) and $600 \mu \mathrm{L}$ of phenol-chloroform-isoamyl alcohol (25:24:1) were added prior to centrifugation for $25 \mathrm{~min}$ at $11,300 \times \mathrm{g}$. The top layer was recovered, and $500 \mu \mathrm{L}$ of cold isopropanol was added and maintained at $-20{ }^{\circ} \mathrm{C}$ for $18 \mathrm{~h}$ before centrifugation (15 min at 17,100 g). The supernatant was decanted, and the pellet was allowed to dry at room temperature. Finally, $50 \mu \mathrm{L}$ of RNase $(20 \mathrm{mg} / \mathrm{mL})$ was added, and the solution was incubated at $37^{\circ} \mathrm{C}$ for $1 \mathrm{~h}$. DNA extraction was confirmed by agarose gel electrophoresis $(0.8 \%$ agarose $)$ at $100 \mathrm{~V}$ for $30 \mathrm{~min}$. DNA extracts were stored at $-20^{\circ} \mathrm{C}$ until used as templates for the PCR reaction.

\subsection{Primers}

Species identification was based on amplification of the hemolysin gene of $V$. mimicus (vmh) (Shinoda et al., 2004; Sultan et al., 2007). A 390-bp region of $v m h$ was used as amplification primers in this study, Vmh390F: GGTAGCCATCAGTCTTATCACG and Vmh390R: ATCGTGTCCCAATACTTCACCG. These primers were previously reported as species specific (Shi et al., 2000).

\subsection{PCR conditions}

The amplification-reaction mixture contained the following components: $10 \mu \mathrm{L}$ of DNA template, $4 \mu \mathrm{L}$ of dNTPs $\left(200 \mu \mathrm{M}\right.$ each), $2 \mu \mathrm{L}$ of $\mathrm{MgCl}_{2}(25 \mathrm{mM}), 1 \mu \mathrm{L}$ of each primer $(50 \mathrm{pM}), 10 \mu \mathrm{L}$ of $5 \times$ Buffer, and $0.5 \mu \mathrm{L}$ of Taq DNA polymerase ( $5 \mathrm{U}$ ) in a final volume of $57.5 \mu \mathrm{L}$. The PCR reaction was performed in a Perkin Elmer thermal cycler under the following conditions: 1 cycle at $94{ }^{\circ} \mathrm{C}$ for $2 \mathrm{~min} ; 35$ cycles of $95{ }^{\circ} \mathrm{C}$ for $45 \mathrm{sec}, 54{ }^{\circ} \mathrm{C}$ for $45 \mathrm{sec}$ and $72{ }^{\circ} \mathrm{C}$ for $35 \mathrm{sec}$; and 1 cycle at $72{ }^{\circ} \mathrm{C}$ for $5 \mathrm{~min}$. V. mimicus CAIM 602 (ATCC 33653) and Escherichia coli (K88) were used as positive and negative controls, respectively. Additionally, $V$. cholerae CAIM 1410, V. cholerae CAIM 1409 and V. parahaemolyticus CAIM 1772 were tested to confirm primer specificity. PCR products were visualized in $1.8 \%$ agarose gel electrophoresis ( $95 \mathrm{~V}$ for $80 \mathrm{~min}$ ). Samples that showed the 390-bp fragment corresponding to the $v m h$ gene region were reported as V. mimicus-positive.

\subsection{Statistical Analysis}

The percentage of $V$. mimicus-positive samples was calculated, and the result was referred to as the $V$. mimicus incidence. The incidence for statistical purposes was calculated for total fish and seafood samples, type of product (crustaceans, fish and mollusks), sample condition (raw and ready to eat-RTE), county (coastal and non-coastal) and sampling month. Results were analyzed using S JMP® V 9.0.2 (2010 SAS Institute Inc) program for multivariate analysis to compare all calculated incidences $(\mathrm{P}<0.05)$.

\section{Results}

\subsection{PCR Specificity}

Specificity for the detection of the $v m h$ gene of $V$. mimicus is shown in Figure 2. Negative results were obtained for $V$. cholerae, $V$. parahaemolyticus and the negative control E. coli. Only $V$. mimicus produced the expected 390 -bp fragment of the $v m h$ gene, which corroborate the specificity of these primers. 


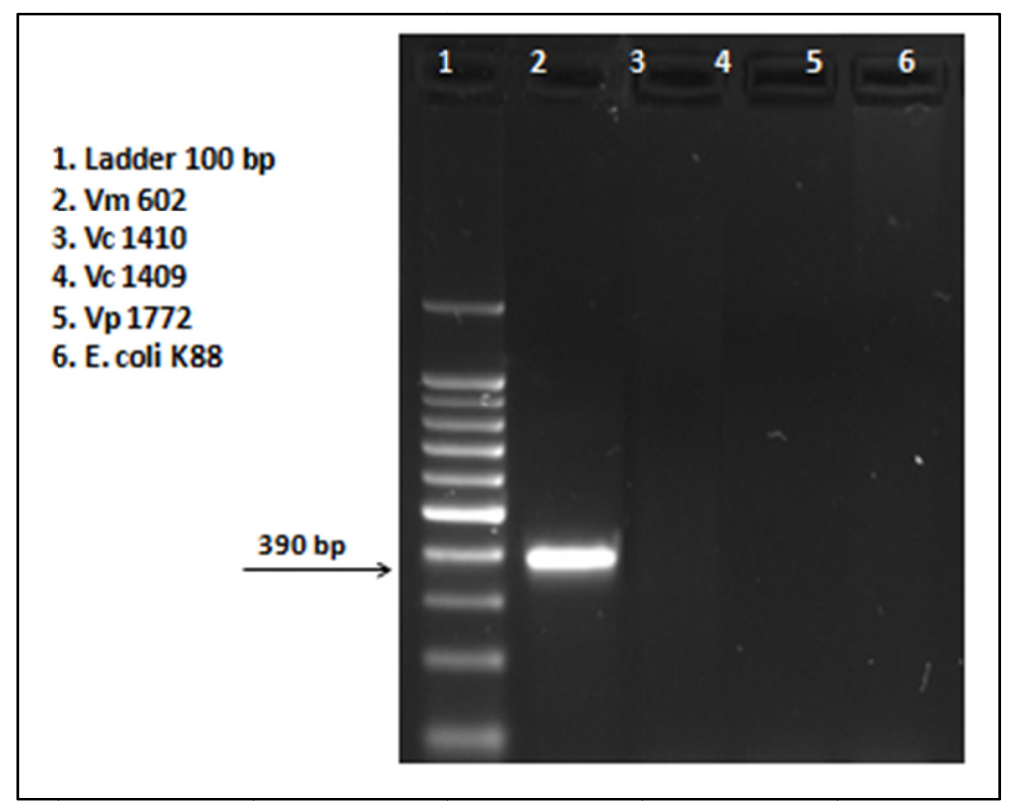

Figure 2. Amplification of the 390-bp fragment of the hemolysin gene ( $v m h)$ of $V$. mimicus: 1 . Ladder 100bp; 2. V. mimicus CAIM 602; 3. V. cholerae CAIM 1410; 4. V. cholerae CAIM 1409; 5. V. parahaemolyticus CAIM 1772; 6. E. coli K88

\subsection{Detection of V. mimicus Hemolysin Gene Using PCR}

Sample frequency by product type and detection of the vmh gene of $V$. mimicus in fish and seafood samples is show in Table 1 . Thirty-two of the 262 samples analyzed were positive $(12 \%)$, and a higher percentage was observed in raw $(14 \%)$ than ready-to-eat products $(9 \%)$. Crustaceans $(20 \%)$ had the highest detection rate, followed by fish (11\%) and mollusks (8\%). Positive correlations were observed between the total incidence of $V$. mimicus and RTE $(\mathrm{P}<0.0016)$, raw $(\mathrm{P}<0.0052)$, crustaceans $(\mathrm{P}<0.0076)$ and mollusks $(\mathrm{P}<0.0018)$ groups, but not fish products. Table 2 shows the distribution of positive raw and RTE seafood samples by product type. From the 23 positive $V$. mimicus raw samples, $57 \%$ corresponded to crustaceans, and 7 out of 9 positive RTE samples were mollusks (78\%).

Month and county distributions of positive samples are presented in Figure 3 and Table 3, respectively. The highest incidence of $V$. mimicus was detected in July, and a positive correlation with crustaceans and mollusks was observed. The incidence of fish products was most associated to June, which was not significantly correlated with any other product. The county analysis showed no differences between coastal (12\%) and non-coastal (14\%) counties. Guaymas and Cajeme were the coastal counties with the highest incidences, and Santa Ana and Agua Prieta were the non-coastal counties with the highest incidences.

Table 1. Percentages of positive samples for the $v m h$ gene of $V$. mimicus by product type as detected by PCR

\begin{tabular}{cllc}
\hline \multirow{2}{*}{ Samples } & \multicolumn{2}{l}{ Positives Samples } \\
\cline { 3 - 4 } & & No. & $\mathbf{( \% )}$ \\
\hline Total Samples & 262 & 32 & 12 \\
\hline Raw Products & 164 & 23 & 14 \\
RTE $^{1}$ & 98 & 9 & 9 \\
\hline Crustaceans & 74 & 15 & 20 \\
Fish & 66 & 7 & 11 \\
Mollusks & 122 & 10 & 8 \\
\hline
\end{tabular}

${ }^{1}$ RTE: ready-to-eat products, including fully cooked or seafood intended for raw consumption. 
Table 2. Distribution of $V$. mimicus-positive raw and RTE seafood samples by product type

\begin{tabular}{lllll}
\hline & Raw & \multicolumn{3}{l}{ RTE } \\
\cline { 2 - 5 } & $\begin{array}{l}\text { Positive } \\
\text { samples }\end{array}$ & $(\%)$ & $\begin{array}{l}\text { Positive } \\
\text { samples }\end{array}$ & $(\%)$ \\
\hline V. mimicus (+) samples & 23 & 57 & 9 & 22 \\
Crustaceans (\%) & 13 & 30 & 0 & 0 \\
Fish (\%) & 7 & 13 & 7 & 78 \\
Mollusks (\%) & 3 & 5 & \\
\hline
\end{tabular}

RTE: ready-to-eat fish or seafood products, includes fully, partially cooked or seafood intended for raw consumption.

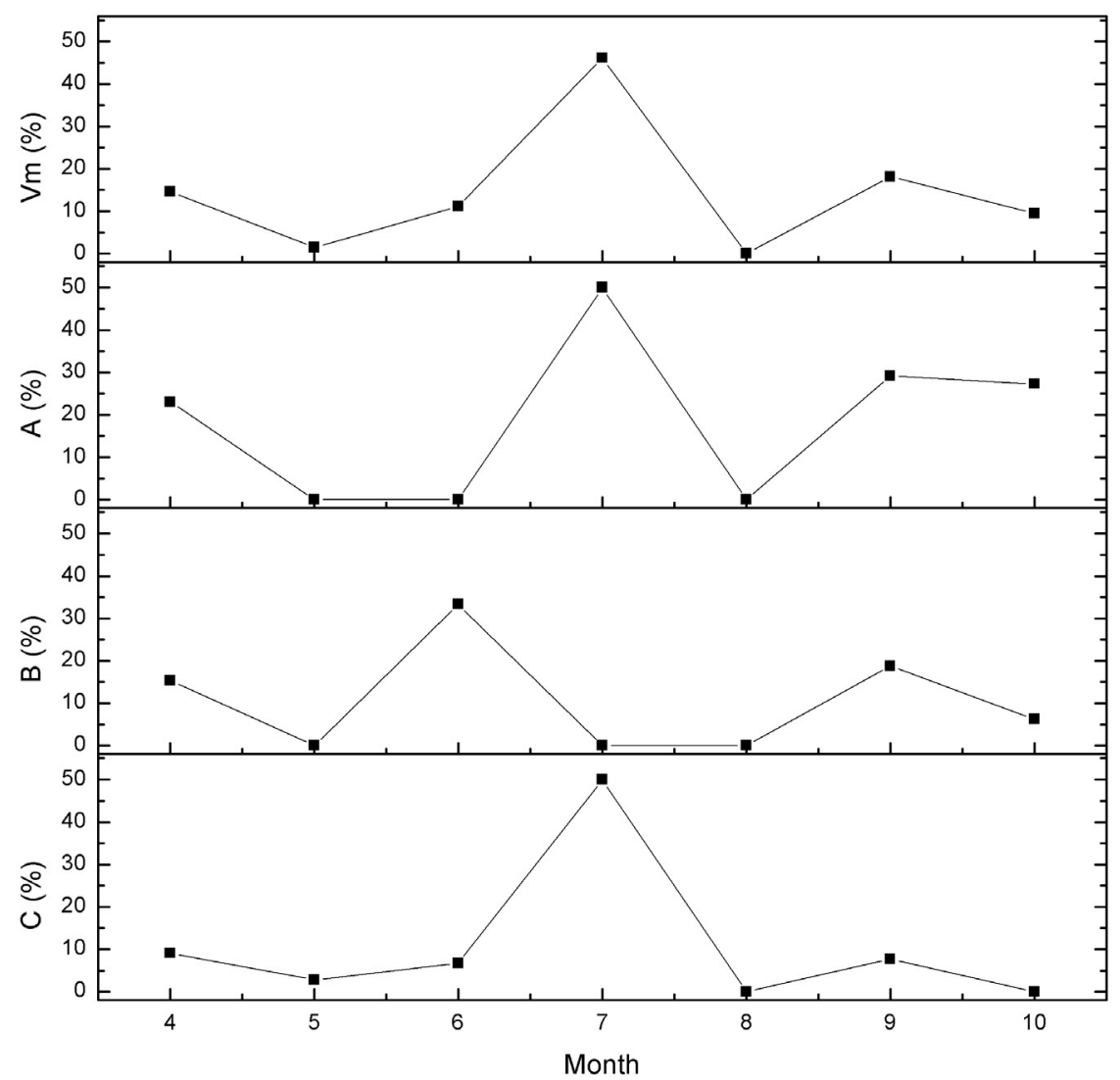

Figure 3. Percentage of monthly detection of $V$. mimicus in seafood samples using PCR of the $v m h$ gene in different seafood samples. Vm: total seafood samples positive to $V$. mimicus, A: crustacean samples positive to $V$. mimicus, B: fish samples positive to $V$. mimicus and, C: mollusks samples positive to $V$. mimicus 
Table 3. Total of $V$. mimicus-positive samples by location type: coastal or non-coastal county

\begin{tabular}{lllll}
\hline \multirow{2}{*}{ Location } & Counties & $\begin{array}{l}\text { No. } \\
\text { Samples }\end{array}$ & of & No. \\
& Positives & Positives \\
\hline Coastal & & $\mathbf{1 8 2}$ & $\mathbf{2 3}$ & $\mathbf{1 2 . 6}$ \\
\hline & Cajeme & 22 & 4 & 18.2 \\
& Guaymas & 50 & 9 & 18 \\
& San Luis Río Colorado & 19 & 3 & 15.8 \\
& Pto. Peñasco & 17 & 2 & 11.8 \\
& Hermosillo & 39 & 4 & 10.3 \\
& Huatabampo & 19 & 1 & 5.3 \\
& Caborca & 16 & 0 & 0 \\
\hline Non-coastal counties & & $\mathbf{8 0}$ & $\mathbf{9}$ & $\mathbf{1 1 . 2}$ \\
& Santa Ana & 9 & 2 & 22.2 \\
& Agua Prieta & 15 & 3 & 20 \\
& Magdalena de Kino & 12 & 2 & 16.7 \\
& Nogales & 13 & 2 & 15.4 \\
& Cananea & 11 & 0 & 0 \\
& Navojoa & 14 & 0 & 0 \\
& Moctezuma & 6 & 0 & 0 \\
\hline
\end{tabular}

\section{Discussion}

The presence of Vibrio species that are associated with marine ecosystems worldwide has been widely documented (Adeleye et al., 2010; Begum \& Khan, 2001; Chitov et al., 2009; Eyisi, Nwodo, \& Iroegbu, 2013). In this study, $12 \%$ of the food samples were positive for the $v m h$ gen of $V$. mimicus, which was more common in raw (14\%) than RTE products (9\%). Additionally, V. mimicus was more frequently detected in crustaceans $(20 \%)$ followed by fish $(11 \%)$ and mollusks $(8 \%)$. Most of the crustacean samples were raw products and mollusks as RTE. Crustaceans, especially shrimp and mollusks, are products that are widely consumed without further heat treatment, which may present a higher risk to the consumer. The values obtained in this study are higher than the values reported for raw seafood by Franco-Monsreal et al. (2003), who detected the presence of V. mimicus in $7.7 \%$ of raw food samples and $1.5 \%$ of partially cooked food, but not in fully cooked foods. In contrast, Tercero Alburo (2008) isolated strains of V. mimicus from fish (5), oysters (9) and water samples (6) taken from the Pueblo Viejo Lagoon in Veracruz, Mexico and found that these strains were gene virulence carriers, which demonstrate their pathogenic potential. V. mimicus in Lagos, Nigeria was detected in $22.7 \%$ of the seafood samples analyzed (shrimp, crabs and mollusks), whereas $V$. cholerae was detected in only $6.8 \%$ of these samples. $V$. mimicus strains are not enterotoxigenic, but they have the capacity to lyse red blood cells and invade intestinal epithelial cells. Therefore, this pathogen could cause infections in humans (Adeleye et al., 2010). Recently, high loads of Vibrio species were found in crayfish, lobster and water samples from the southeastern Atlantic coast of Nigeria. The species identified were $V$. cholerae, $V$. parahaemolyticus, $V$. vulnificus, $V$. fluvialis and $V$. mimicus. $V$. mimicus was most often isolated in lobster $(21.4 \%)$ and crayfish (21.5\%) (Eyisi et al., 2013). Differences in the frequency of $V$. mimicus detection in food products between regions may be due to several factors, including the initial contamination level, product handling at inadequate temperatures and cross-contamination after capture. The initial level or origin contamination could be affected by environmental parameters because temperature, salinity, and conductivity, among others, affect Vibrio occurrence in marine environments (Caburlotto et al., 2012; Collin \& Rehnstam-Holm, 2011; León Robles et al., 2013). However, factors such as temperature and hygienic handling must to be controlled along the productive food chain to reduce the survival and growth of Vibrio species and other pathogenic bacteria (Boonyawantang, Mahakarnchanakul, Rachtanapun, \& Boonsupthip, 2012; Nunes et al., 2010).

The $v m h$ gene of $V$. mimicus was detected at low levels in RTE seafood products $(9 \%)$, but these products will not have heat treatment before eating, and the consumer health risks need to be addressed. Notably, most 
crustaceans were in the raw form and represented the highest percentage of positive samples. Proper cooking of food products is sufficient to eliminate $V$. mimicus (Adeleye et al., 2010; Chitov et al., 2009). Therefore, its detection in cooked products leads us to assume that inadequate cooking or cross-contamination after heat treatment because of poor handling procedures had occurred.

The association of different species of the genus Vibrio with crustaceans, especially shrimp or shrimp-shells, has been widely documented (Aguirre-Guzman, Mejia Ruiz, \& Ascencio, 2004; Manilal et al., 2010; Somboon, Purivirojkul, Limsuwan, \& Chrchird, 2012). One of the major components of crustaceans shells, chitin, has also been reported to have a protective effect on Vibrio species (Pruzzo, Vezzulli, \& Colwell, 2008; Vezzulli, Pruzzo, Huq, \& Colwell, 2010). Therefore, it is not surprising that crustaceans were the most commonly contaminated product. The highest incidence of positive crustacean samples was found in July and September, which are initial months of aquaculture product harvesting and wild-shrimp season. These factors increase crustacean availability as a fresh product and its raw consumption.

The presence of $v m h$ in fish samples was detected only in raw products, with the highest incidences in July and September. Therefore, no RTE samples were positive, and the low incidence in fish (11\%) suggests that these products are low risk if the product is properly handled after catch.

Mollusk samples showed the lowest incidence (8\%), but these samples were the main positive seafood type in RTE products (78\%). More than half of the positive mollusk samples were raw bivalves on shells during July, and the rest were fully cooked mollusks. Cross-contamination plays an important role in the presence of $V$. mimicus and other pathogenic bacteria in cooked products (Center for Disease Control and Prevention [CDC], 2010); but also the ambient temperature for fresh bivalve mollusks such oysters, particularly in Sonora were the highest average temperatures occur during July and August (Instituto Nacional de Estadistica y Geografía [INEGI], 2010).

The counties with the highest percentages of $V$. mimicus-positive samples were Cajeme (18.2\%) and Guaymas $(18.0 \%)$ as coastal counties and Santa Ana (22.2\%) and Agua Prieta (20.0\%) as non-coastal counties. However, there was no difference in the incidence of $V$. mimicus between coastal (12.6\%) or non-coastal $(11.2 \%)$ counties. The number of samples collected per county was not identical because more samples were collected in counties with larger populations, which were normally found in the coastal area. The seasonality of some seafood products also reduces product availability in smaller or non-coastal counties throughout the year, and more data are needed for comparison between these counties.

Month distribution did not show the common warm-weather patterns that were reported for other Vibrio species (Centers for Disease Control and Prevention [CDC], 2012; Hlady \& Klontz, 1996). This study showed three peaks of incidence for $V$. mimicus, April, July and September, with the highest incidence in July because of crustaceans and mollusks. However, the sampling period did not encompass a full year, only the warmest months. Nevertheless, there are differences in ambient temperature between July-September $\left(>30^{\circ} \mathrm{C}\right)$ and April $\left(<25^{\circ} \mathrm{C}\right)$. Analyses of the distribution of $V$. mimicus infections per month in Florida from 1981 to 1993 showed that the highest incidences occurred during July, April and March also without a seasonal pattern, like $V$. vulnificus and other Vibrio species (Hlady \& Klontz, 1996). There are no official statistics of $V$. mimicus in Mexico, and the real impact of this bacterium on the health of Mexican population is unknown. However, it is well known that most cases of Vibrio infections occur during the summer months (Centers for Disease Control and Prevention [CDC], 2014). A previous study of the environmental factors affecting the abundance of some Vibrio species, including $V$. mimicus, in the area of Guaymas, Mexico showed good correlation between the abundance and ambient parameters (temperature, salinity, $\mathrm{pH}$, among others) and some Vibrio species. However, environmental conditions could not fully explain the behavior of $V$. mimicus and its abundance should be influenced by others parameters (León Robles et al., 2013). Therefore, the low incidence of these bacteria in natural environments, its association by product type or other external or environmental factors could affect its frequency in fish and seafood products.

However, the State of Sonora accounts for $49 \%$ of the national fish and seafood production (catches and aquacultures), and it is one of the main shrimp-exporting regions in Mexico (Oficina Estatal de Información para el Desarrollo Rural Sustentable del Estado de Sonora [OEIDRUS], 2010, 2011). Therefore, the sanitary condition of Mexican fish and seafood products has a great impact on the health of countries other than Mexico. The need to expand this study to assess the economic and health impact for $V$. mimicus and other pathogenic Vibrio species is evident. The collection of more data on the consumption of marine products by species is also highly recommended to determine the potential risk to the population. 


\section{Conclusions}

$V$. mimicus may represent a potential health risk because it was detected in raw and RTE products. Raw crustaceans and mollusks are the products of major concern, but fish may be considered a low-risk product because of its low incidence. Crustaceans were the most commonly contaminated product, with a high frequency at the beginning of the harvest and wild season. Mollusks were the most common RTE product associated to $V$. mimicus. The presence of total $\mathrm{V}$. mimicus in fish and seafood showed no seasonal patterns, and no differences in coastal and non-coastal counties were found. Therefore, the presence of $V$. mimicus in seafood products may be due to several factors, including the initial contamination level, product type, product handling, food chain and cross-contamination after capture. This study demonstrated the need to understand and analyze patterns of fish and seafood consumption, and handling practices for fish and seafood. In addition to the detection of pathogenic species, various virulence factors that are associated with $V$. mimicus should be monitored to determine their infective potential and possible effects on consumer health.

\section{Acknowledgments}

We are grateful to the Sonora State Public Health Laboratory (LESP) and particularly to Jesús Adán Grijalva Matus, Carolina Avila Cervantes, Ana Guadalupe Valle Velázquez and Verónica Corona Escamilla for their valuable assistance with the initial handling and processing of the samples that were analyzed. Additionally, to Elsa Evelia López Álvarez of the CIAD-Guaymas for the excellent support provided during sample analysis.

\section{References}

Adeleye, I. A., Daniels, F. V., \& Enyinnia, V. A. (2010). Characterization And Pathogenicity of Vibrio spp. Contaminating Seafoods In Lagos, Nigeria. Internet Journal of Food Safety, 12, 1-9. Retrieved from http://www.internetjfs.org/articles/ijfsv12-1.pdf

Aguirre-Guzman, G., Mejia Ruiz, H., \& Ascencio, F. (2004). A review of extracellular virulence product of Vibrio species important in diseases of cultivated shrimp. Aquaculture Research, 35(15), 1395-1404. http://dx.doi.org/10.1111/j.1365-2109.2004.01165.x

Begum, A., \& Khan, S. I. (2001). Abundance of Vibrio cholerae non-O1 and Vibrio mimicus in Various Aquatic Components of the Pond Ecosystem in Matlab, Bangladesh. Microbes and Environments, 16(1), 19-23. http://dx.doi.org/10.1264/jsme2.2001.19

Boonyawantang, A., Mahakarnchanakul, W., Rachtanapun, C., \& Boonsupthip, W. (2012). Behavior of pathogenic Vibrio parahaemolyticus in prawn in response to temperature in laboratory and factory. Food Control, 26(2), 479-485. http://dx.doi.org/10.1016/j.foodcont.2012.02.009

Caburlotto, G., Bianchi, F., Gennari, M., Ghidini, V., Socal, G., Aubry, F. B., ... Lleo, M. M. (2012). Integrated Evaluation of Environmental Parameters Influencing Vibrio Occurrence in the Coastal Northern Adriatic Sea (Italy) Facing the Venetian Lagoon. Microbial Ecology, 63(1), 20-31. http://dx.doi.org/10.1007/s00248-011-9920-x

Campos, E., Bolaños, H., Acuña, M. T., Díaz, G., Matamoros, M. C., Raventós, H., ... Barquero, C. (1996). Vibrio mimicus diarrhea following ingestion of raw turtle eggs. Applied and Environmental Microbiology, 62(4), 1141-4.

Center for Disease Control and Prevention (CDC). (2010). Notes from the field: Vibrio mimicus infection from consuming crayfish - Spokane, Washington, June 2010., 59 MMWR. Morbidity and mortality weekly report 1374 (2010).

Centers for Disease Control and Prevention (CDC). (2012). Foodborne Diseases Active Surveillance Network (FoodNet): 2011 SurveFoodNet Surveillance Report for 2011. Atlanta, Gerogia. Retrieved from http://www.cdc.gov/ncezid/dfwed/edeb/reports.html

Centers for Disease Control and Prevention (CDC). (2014). Foodborne Diseases Active Surveillance Network (FoodNet): FoodNet Surveillance Report for 2012 (Final Report). Atlanta, Georgia, U.S. Retrieved from $\mathrm{http}: / /$ www.cdc.gov/foodnet/PDFs/2012_annual_report_508c.pdf

Chitov, T., Kirikaew, P., Yungyune, P., Ruengprapan, N., \& Sontikun, K. (2009). An incidence of large foodborne outbreak associated with Vibrio mimicus. European Journal of Clinical Microbiology \& Infectious Diseases: Official Publication of the European Society of Clinical Microbiology, 28(4), 421-4. http://dx.doi.org/10.1007/s10096-008-0639-7 
Chowdhury, M. A. R., Yamanaka, H., Miyoshi, S., Aziz, K. M. S., \& Shinoda, S. (1989). Ecology of Vibrio mimicus in Aquatic Environments. Applied and Environmental Microbiology, 55(8), 2073-2078.

Collin, B., \& Rehnstam-Holm, A.-S. (2011). Occurrence and potential pathogenesis of Vibrio cholerae, Vibrio parahaemolyticus and Vibrio vulnificus on the South Coast of Sweden. FEMS Microbiology Ecology, 78(2), 306-313. http://dx.doi.org/10.1111/j.1574-6941.2011.01157.x

Daniels, N. A., \& Shafaie, A. (2000). A Review of Pathogenic Vibrio Infections for Clinicians. Infections in Medicine, 17(10), 665-685.

Davis, B. R., Fanning, G. R., Madden, J. M., Steigerwalt, a G., Bradford, H. B., Smith, H. L., \& Brenner, D. J. (1981). Characterization of biochemically atypical Vibrio cholerae strains and designation of a new pathogenic species, Vibrio mimicus. Journal of Clinical Microbiology, 14(6), 631-9.

Eyisi, O. A. L., Nwodo, U. U., \& Iroegbu, C. U. (2013). Distribution of Vibrio species in Shellfish and Water Samples Collected from the Atlantic Coastline of South-East Nigeria. Journal of Health, Population, and Nutrition, 31(3), 314-20.

Farmer III, J. (2006). The Family Vibrionaceae. In M. Dworkin, S. Falkow, E. Rosenberg, K.-H. Schleifer, \& E. Stackebrandt (Eds.), The Prokaryotes Vol 6 (pp. 495-507). Singapore: Springer New York. http://dx.doi.org/10.1007/0-387-30746-X_17

Farmer III, J. J., Janda, Mi. J., Brenner, F. W., Cameron, D. N., \& Birkhead, K. M. (2005). Genus I. Vibrio. In D. J. Brenner, N. R. Krieg, \& J. T. Staley (Eds.), Bergey's Manual of Systematic Bacteriology Vol.2 (2nd ed., pp. 494-555). Springer.

Foley, S. L., \& Grant, K. (2007). Molecular Techniques of Detection and Discrimination of Foodborne Pathogens and Their Toxins. In S. Simjee (Ed.), Infections Disease: Fodborne Diseases (pp. 485-510). TotowaHumana Press Inc.

Franco-Monsreal, J., Flores-Abuxapqui, J. J., Suárez-Hoil, G. de J., Puc-Franco, M. A., Heredia-Navarrete, M. R., \& Vivas-Rose, M. de la L. (2003). PREVALENCIAS DE LAS ESPECIES Vibrio hollisae, Vibrio mimicus y Vibrio vulnificus EN ALIMENTOS MARINOS DE ORIGEN ANIMAL DE MARISQUERÍAS DE LA CIUDAD DE CHETUMAL, QUINTANA ROO, MÉXICO. Revista de Salud Pública Y Nutrición, 4(1). Retrieved from http://www.respyn.uanl.mx/iv/1/articulos/vibrio.html

Gonzalez Vazquez, E., Tercero Alburo, J. J., Quiñones-Ramírez, E. I., \& Vazquez Salinas, C. (2005). El hermano pequeño del cólera vibrio mimicus. Revista Digital Universitaria, 6(4), 1-8. Retrieved from http://www.revista.unam.mx/vol.6/num4/art34/abr_art34.pdf

Hasan, N. a, Grim, C. J., Haley, B. J., Chun, J., Alam, M., Taviani, E., ... Colwell, R. R. (2010). Comparative genomics of clinical and environmental Vibrio mimicus. Proceedings of the National Academy of Sciences of the United States of America (PNAS), 107(49), 21134-9. http://dx.doi.org/10.1073/pnas.1013825107

Hlady, W. G., \& Klontz, K. C. (1996). The Epidemiology of Vibrio Infections in Florida, 1981-1993. Journal of Infectious Diseases, 173(5), 1176-1183. http://dx.doi.org/10.1093/infdis/173.5.1176

Instituto Nacional de Estadistica y Geografía (INEGI). (2010). México: Información por Entidad, División Municipal, 2010. Retrieved September 05, 2014, from http://cuentame.inegi.org.mx/monografias/informacion/son/territorio/div_municipal.aspx?tema=me

Kaysner, C. A., \& DePaola, A. (2004). Vibrio. In (Food and Drug Adminsitration) (Ed.), Bacteriological Analytical Manual. FDA. Retrieved from http://www.fda.gov/Food/FoodScienceResearch/LaboratoryMethods/ucm070830.htm

León Robles, a, Acedo Félix, E., Gomez-Gil, B., Quiñones Ramírez, E. I., Nevárez-Martínez, M., \& Noriega-Orozco, L. (2013). Relationship of aquatic environmental factors with the abundance of Vibrio cholerae, Vibrio parahaemolyticus, Vibrio mimicus and Vibrio vulnificus in the coastal area of Guaymas, Sonora, Mexico. Journal of Water and Health, 11(4), 700-12. http://dx.doi.org/10.2166/wh.2013.160

Manilal, A., Sujith, S., Selvin, J., Shakir, C., Gandhimathi, R., \& Kiran, G. S. (2010). Virulence of Vibrios Isolated from Diseased Black Tiger Shrimp, Penaeus monodon, Fabricius. Journal of the World Aquaculture Society, 41(3), 332-343. http://dx.doi.org/10.1111/j.1749-7345.2010.00375.x

Mizuno, T., Nanko, A., Maehara, Y., Shinoda, S., \& Miyoshi, S.-I. (2014). A novel extracellular protease of Vibrio mimicus that mediates maturation of an endogenous hemolysin. Microbiology and Immunology, 58(9), 503-12. http://dx.doi.org/10.1111/1348-0421.12177 
Mizuno, T., Sultan, S. Z., Kaneko, Y., Yoshimura, T., Maehara, Y., Nakao, H., ... Miyoshi, S. (2009). Modulation of Vibrio mimicus hemolysin through limited proteolysis by an endogenous metalloprotease. The FEBS Journal, 276(3), 825-34. http://dx.doi.org/10.1111/j.1742-4658.2008.06827.x

Muñoz, D., Marín, C. G. De, Marval, H., \& Martínez, C. (2012). Identification of Bacteria of the Genus Vibrio Associated to Zones of Bivalve Mollusks Extraction, sucre State, Venezuela. Revista Científica, XXII(5), 459-467. Retrieved from http://www.redalyc.org/articulo.oa?id=95923384010

Newton, A., Kendall, M., Vugia, D. J., Henao, O. L., \& Mahon, B. E. (2012). Increasing Rates of Vibriosis in the United States, 1996-2010: Review of Surveillance Data From 2 Systems. Clinical Infectious Diseases, 54(Suppl 5), S391-5. http://dx.doi.org/10.1093/cid/cis243

Noriega-Orozco, L., Acedo-Félix, E., Higuera-Ciapara, I., Jiménez-Flores, R., \& Cano, R. (2007). Pathogenic and non pathogenic Vibrio species in aquaculture shrimp ponds. Revista Latinoamericana de Microbiología, 49(3-4), 60-67. Retrieved from http://www.medigraphic.com/pdfs/lamicro/mi-2007/mi07-3_4d.pdf

Nunes, B. N., Cruz, A. G., Faria, J. a. F., Sant' Ana, A. S., Silva, R., \& Moura, M. R. L. (2010). A survey on the sanitary condition of commercial foods of plant origin sold in Brazil. Food Control, 21(1), 50-54. http://dx.doi.org/10.1016/j.foodcont.2009.03.016

Ochman, H. (2001). Evolution of Bacterial Pathogens. In E. A. Groisman (Ed.), Principles of Bacterial Pathogenesis (pp. 1-41). San Diego, California, USA: ACADEMIC PRESS. http://dx.doi.org/10.1016/B978-012304220-0/50002-9

Oficina Estatal de Información para el Desarrollo Rural Sustentable del Estado de Sonora (OEIDRUS). (2010). Sonora lider en producción de diversos productos agropecuarios y pesqueros. Retrieved September 02, 2014, from http://www.oeidrus-sonora.gob.mx/documentos/PUBLICACION DINAMICA/5 estados PDF.pdf

Oficina Estatal de Información para el Desarrollo Rural Sustentable del Estado de Sonora (OEIDRUS). (2011). Sonora producción pesquera del periodo enero - noviembre 2011. Retrieved September 05, 2014, from http://www.oeidrus-sonora.gob.mx/documentos/Pesca/Producci\%C3\%B3npesquera-Enero-Noviembre 2011.pdf

Prakash, O., Verma, M., Sharma, P., Kumar, M., Kumari, K., Singh, A., ... Lal, R. (2007). Polyphasic approach of bacterial classification - An overview of recent advances. Indian Journal of Microbiology, 47(2), 98-108. http://dx.doi.org/10.1007/s12088-007-0022-x

Pruzzo, C., Vezzulli, L., \& Colwell, R. R. (2008). Global impact of Vibrio cholerae interactions with chitin. Environmental Microbiology, 10(6), 1400-10. http://dx.doi.org/10.1111/j.1462-2920.2007.01559.x

Ramamurthy, T., \& Nair, G. B. (2007). Foodborne Pathogenic Vibrios. In E. Simjee (Ed.), Infections Disease: Foodborne Diseases (pp. 115-156). Totowa Humana Press Inc.

Saad, M. S., Edris, A. M., Ibrahim-Hemmat, M., \& Rasha, A. E. E. (2013). Detection of Vibrio species in Clams. The Global Journal of Fisheries and Aquacutlure Research, 6(6), 90-100.

Shi, L., Miyoshi, S., Bi, K., Nakamura, M., Hiura, M., Tomochika, K., \& Shinoda, S. (2000). Presence of Hemolysin Genes (vmh, tdh and hlx) in Isolates of Vibrio mimicus Determined by Polymerase Chain Reaction. Journal of Health, 46(1), 63-65. Retrieved from http://jhs.pharm.or.jp/data/46(1)/46(1)p63.pdf

Shinoda, S., Nakagawa, T., Shi, L., Bi, K., Kanoh, Y., Tomochika, K., ... Shimada, T. (2004). Distribution of Virulence-Associated Genes in Vibrio mimicus Isolates from Clinical and Environmental Origins. Microbiology and Immunology, 48(7), 547-551. http://dx.doi.org/10.1111/j.1348-0421.2004.tb03551.x

Somboon, M., Purivirojkul, W., Limsuwan, C., \& Chrchird, N. (2012). Effect of Vibrio spp. in White Feces Infected Shrimp in Chanthaburi, Thailand. Kasetsrt University Fisheries Research Bulletin, 36(1), 7-15. Retrieved from http://www.fish.ku.ac.th/pdf/Bulletin36-1-2.pdf

Sultan, Z., Mizuno, T., Sakurai, A., Takata, N., Okamoto, K., \& Miyoshi, S. (2007). Growth Phase Dependant Activation of the Precursor of Vibrio mimicus Hemolysin (Pro-VMH). Journal of Health Science, 53(4), 430-434. http://dx.doi.org/10.1248/jhs.53.430

Tercero Alburo, J. J. (2008). Detección de posibles factores de virulencia de Vibrio mimicus aislado de agua y alimentos. (Master Thesis Instituo Politécnico Nacional, Mexico). Retrieved from http://tesis.ipn.mx:8080/xmlui/bitstream/handle/123456789/4276/DETECCIONPOSIBLES.pdf?sequence= 1 
Thompson, F. L., Iida, T., \& Swings, J. (2004). Biodiversity of Vibrios. Microbiology and Molecular Biology Reviews, 68(3), 403-431.

Vezzulli, L., Pruzzo, C., Huq, A., \& Colwell, R. R. (2010). Environmental reservoirs of Vibrio cholerae and their role in cholera. Environmental Microbiology Reports, 2(1), 27-33. http://dx.doi.org/10.1111/j.1758-2229.2009.00128.x

Vieira, V. V, Teixeira, L. F., Vicente, a C., Momen, H., \& Salles, C. a. (2001). Differentiation of environmental and clinical isolates of Vibrio mimicus from Vibrio cholerae by multilocus enzyme electrophoresis. Applied and Environmental Microbiology, 67(5), 2360-4. http://dx.doi.org/10.1128/AEM.67.5.2360-2364.2001

Wong, H.-C., Chen, L.-L., \& Yu, C.-M. (1994). Survival of Psychrotrophic Vibrio mimicus, Vibrio fluvialis and Vibrio parahaemolyticus in Culture Broth at Low Temperatures. Journal of Food Protection, 7, 607-610.

Zamudio, M. L. (2005). CONFIRMACIÓN DE AISLAMIENTOS DE Vibrio mimicus DEL BROTE DE INTOXICACIÓN ALIMENTARIA EN CUNCASHCA, CARHUAZ. Boletín Instituto Nacional de Salud $\begin{array}{llll}\text { (Peru), } & 11(3-4), & \text { 75-76. } & \text { Retrieved }\end{array}$ http://www.ins.gob.pe/RepositorioAPS/0/0/par/BOLETIN_2005/Boletin Marzo Abril 2005.pdf

\section{Copyrights}

Copyright for this article is retained by the author(s), with first publication rights granted to the journal.

This is an open-access article distributed under the terms and conditions of the Creative Commons Attribution license (http://creativecommons.org/licenses/by/3.0/). 